\title{
Central bank responses to COVID-19
}

\author{
Patricia C. Mosser ${ }^{1}$
}

Published online: 13 November 2020

(c) National Association for Business Economics 2020

\begin{abstract}
Central bank responses to COVID-19 have been extraordinary in speed, in size and in scope. Much easier monetary policy, massive liquidity provision, and targeted credit support to the real economy all played a role in stabilizing financial conditions and credit. On net, there is preliminary evidence that central bank actions have been a positive-for access to credit and for the real economy - during very trying times. But the first six months have made clear that central bank policy can only indirectly address the core economic policy challenges of the crisis, whose trajectory remains highly uncertain. The risks to the economy and financial system remain very large, and key policy questions—on the degree of fiscal policy support to the real economy, about the limits of central bank risk taking and monetization of debt, and about the wisdom of heavy reliance on central bank policies given their impact on leverage and debt levels—remain just that.
\end{abstract}

Keywords Monetary policy $\cdot$ Lender of last resort $\cdot$ Credit programs $\cdot$ COVID-19 $\cdot$ Central banks $\cdot$ Federal Reserve

Central bank responses to COVID-19 have been extraordinary in speed, in size and in scope. The Federal Reserve announced as many emergency programs in eight days (March 14 to 23, 2020) as it did during all of 2008. Moreover, the Fed implemented more programs in 4 months than in the entire global financial crisis. On net, there is evidence that central bank actions have been a positive - for access to credit and for the real economy-during very trying times. But this early conclusion has two caveats: first, in a pandemic a central bank's role is limited. At best it can cushion the blow via lending and easier financial conditions, and so provide a bridge to future economic recovery. But encouraging more leverage is a double-edge sword, since it can increase future fragility. Second, it is frankly too soon to make a serious judgment on the ultimate effectiveness of any particular set of economic policies-central bank or otherwise.

Thanks to my colleagues in the Columbia University Finance Free Lunch and Macro Lunch Group seminars for comments on an earlier presentation of this material and to Charles Steindel for comments. Particular thanks to Johann Kerhousse and Doris Li for excellent research assistance.

Patricia C. Mosser

pm2816@columbia.edu

1 School of International and Public Affairs, Columbia University, New York, USA
The size and speed of the response by the Fed and other central banks mirror the size and speed of the COVID-19 crisis. Typically, economic crises of this scale are preceded by financial crises. The 2007-2009 global financial crisis is a classic example; it started with a financial panic, which accelerated in spite of large central bank and fiscal interventions. The financial deterioration (panic) happened rapidly, but only over time did it drag the real economy down with it.

This time exactly the opposite happened. The public health restrictions required to manage the pandemic caused enormous, instantaneous (and largely) negative shocks to both aggregate supply and demand. The real economy figuratively stepped off a cliff in March 2020 (see Fig. 1), prompting similarly large and swift policy actions by monetary and fiscal authorities. The huge sectoral differences in the impact of the crisis-shutdowns in many retail services, travel, entertainment, and hospitality, as well as non-Covid, non-emergency health care-led to a sharp drop in overall economic activity, and the prospect of massive unemployment and business failures. The unusual combination of supply and demand shocks will likely have long-term implications for the structure of the economy and growth, and they will remain a challenge for economic policy, including central banks. See Guerrieri et al. (2020).

Importantly, the financial system was quite strong at the beginning of the COVID crisis, reflecting the relatively long global (and U.S.) economic expansion as well as much more 
Index of 10 weekly indicators of real economic activity, scaled to year-over-year percent changes in U.S. real GDP

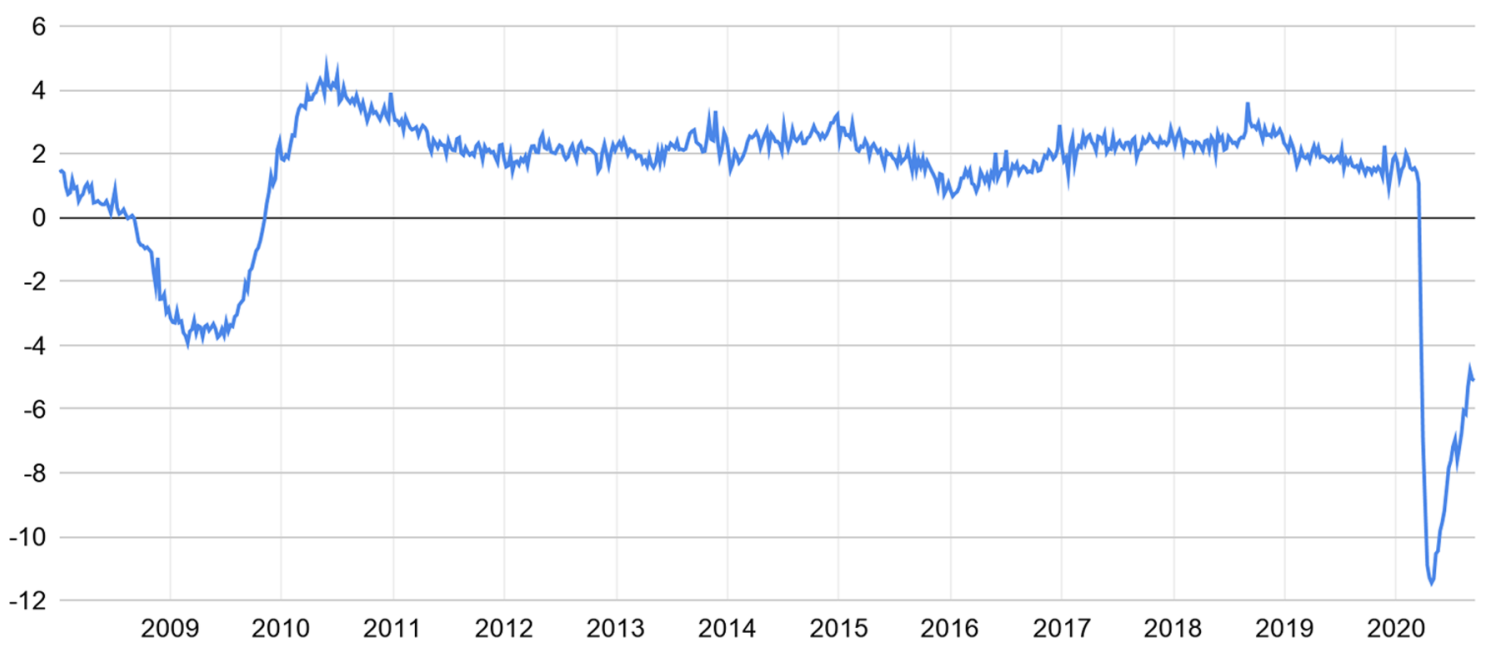

Fig. 1 Weekly Economic Index

Source: Federal Reserve Bank of New York. See Lewis et al. (2020)

robust capital and liquidity buffers in the financial system, particularly at the largest global banks. See Borio (2020). Indeed, one of the aims of central bank (and fiscal) policies since March 2020 has been to provide enough support to the real economy to prevent a large negative feedback loop from real economy bankruptcies and defaults to the financial sector. If the collapse of the real economy causes a subsequent financial crisis, then the United States and world face an even more dire outlook: the collapse of credit formation and liquidity provision by banks and other financial companies, which in turn would cause an even further step down in the economy, employment and well-being.

\section{Central bank policy}

In response to the economic collapse, central banks, including the Fed, launched a massive set of programs to address both the real and financial distress caused by the pandemic. See Fleming et al. (2020). Like the fiscal policy responses, many of the new (or renewed) central bank programs were intended as "cushion the blow" policies to sustain credit formation, support the real economic activity by easing financial conditions, provide liquidity and reduce financial distress. ${ }^{1}$

Central bank policy actions and programs can be roughly broken into three categories: monetary policy, liquidity provision/lender-of-last-resort to the financial system, and

\footnotetext{
${ }^{1}$ For a more comprehensive list of programs across countries, as well as associated changes to regulatory policy, see IMF (2020). and https://docs.google.com/spreadsheets/d/1s6EgMa4KGDfFzcsZJKq wiH7yqkhnCQtW7gI7eHpZuqg/edit\#gid=0.
}

targeted credit programs directed to support nonfinancial sector players: firms, households, municipalities. Importantly, these actions were accompanied by enormous regulatory relief actions, including relaxation of capital and liquidity standards, and loosening of market regulations and activity restrictions in the financial sector, again with the aim to make financing more available at lower cost. ${ }^{2}$

\subsection{Monetary policy}

Easing monetary policy in face of a recession is standard operating procedure. Nearly every central bank on the planet has sharply cut policy interest rates (where they could do so). ${ }^{3}$ In many advanced economies, including the United States policy rates were set to their effective lower bound, and 'unconventional' policies such as asset purchase programs were started or expanded. ${ }^{4}$ Moreover, a number of emerging market central banks not only cut rates but began asset purchase programs (both government and private sector), some doing so for the first time. ${ }^{5}$ One notable exception

\footnotetext{
2 The list of regulatory forbearance actions and macro-prudential measures is much more extensive than the list of central bank policies. It includes easing of reserve requirements and other liquidity requirements, particularly in emerging economies, release of countercyclical capital buffers for banks, delayed implementation of new regulations, easing of market regulations, and reductions in capital requirements, such as leverage ratios, for certain types of assets.

3 Central Bank News (https://www.centralbanknews.info/p/interestrates.html).

${ }^{4}$ Examples include the central banks of Canada, Australia, New Zealand, Sweden, the United Kingdom, Japan and the ECB.

5 Examples include the central banks of Korea, South Africa, Indonesia, India, Thailand, Chile, and Colombia,
} 


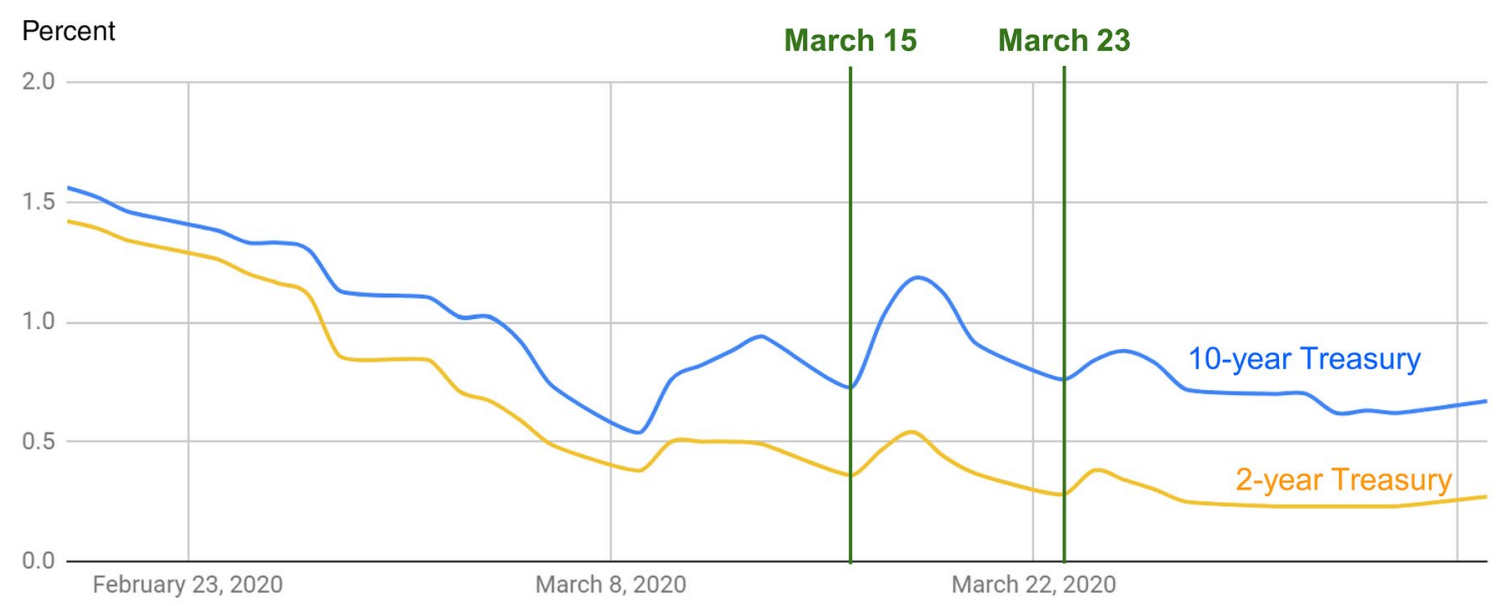

Fig. 2 US Treasury security yields (March-April 2020)

Source: Federal Reserve Board of Governors

is that central banks with negative policy rates did not cut their rates further. ${ }^{6}$

In the case of the Fed, the initial announced size of "QE" asset purchases was immediately and dramatically upsized in reaction to severe dislocations in fixed income and funding markets. On March 15, the FOMC announced asset purchases of $\$ 700$ billion "over the coming months", amounts that were somewhat larger than the overall pace of purchases during QE1 and QE2. (FOMC 2020a). ${ }^{7}$

Prior to the March 15 announcement U.S. Treasury markets were in severe turmoil, with extreme volatility, widening spreads, and a sharp drop in liquidity. In response, the New York Fed's open market desk bought almost $\$ 40$ billion of U.S. Treasuries in a single day, March 13. By the following Thursday, March 19, the desk was purchasing $\$ 75$ billion of Treasuries per day: a pace that was maintained until April $1 .^{8}$ The FOMC officially announced this "whatever size is needed" policy on March 23. (FOMC 2020b). ${ }^{9}$ To give a sense of the extraordinary scale, the desk purchased more U.S. Treasury securities (more than $\$ 800$ billion) in the 15 working days between March 12 and April 1 than during the entire $2+$ years of QE3.

\footnotetext{
${ }^{6}$ Moreover, Sweden's Riksbank, which used negative policy rates in the past, decided not to do so in response to the COVID shock, but instead expanded its asset purchase program.

7 Purchases announced were $\$ 500$ billion of US Treasuries and $\$ 200$ billion of agency mortgage-backed securities (MBS). The composition of purchases was different from QE2 and QE3. QE2 was all US Treasuries, while QE3 was closer to equal shares of US Treasuries and agency MBS.

${ }^{8}$ Information on asset purchases are available at https://www.newyo rkfed.org/markets/pomo/operations/search.

${ }^{9}$ In QE3 the pace of U.S Treasury purchases was $\$ 45$ billion per month.
}

The rationale for the desk becoming "dealer of last resort" is straightforward. Large-scale asset purchase programs are intended to lower term premia and risk premia through portfolio rebalance incentives. But severe turmoil in benchmark Treasury markets pushed in the opposite direction; long-term Treasury yields initially rose, pushing up other long-term interest rates up with them. (See Fig. 2). The typical crisis flight to quality which lowers Treasury yields was more than offset by a flight to liquidity, with widespread selling of Treasuries by leveraged investors for margin calls, by mutual funds to fund record redemptions, and by countries to provide dollar funding to their economies or manage their exchange rates. Massive buying and selling overwhelmed the infrastructure of the market, volatility spiked and market liquidity (ability to trade) evaporated (Fig. 3). See Fleming (2020) and Duffie (2020) for a more complete discussion. There was an immediate spillover to credit markets. The corporate bond market-typically the more liquid investment grade corporate market -was particularly impaired in part because of mutual fund flows. See Gilchrist et al. (2020), Liang (2020), and Ma et al. (2020).

In short, the size of purchases needed to fulfill the FOMC's intent to ease financial conditions needed to be expanded dramatically. The massive asset purchases by the NY Fed desk worked. Yields and volatility fell within days. And because the U.S. Treasury market is the benchmark fixed income market globally, the Fed purchases essentially eased global financial conditions, allowing banks, investment companies, individuals and countries around the world to continue to finance themselves and to intermediate credit.

Asset purchase programs at other large economy central banks were also expanded, although none on the scale of the Fed's actions. In the euro area, economic shutdowns prompted the ECB to undertake additional asset purchases of $€ 750$ billion in March, which was expanded to $€ 1.35$ trillion in June (ECB 2020). The ECB estimates that the 


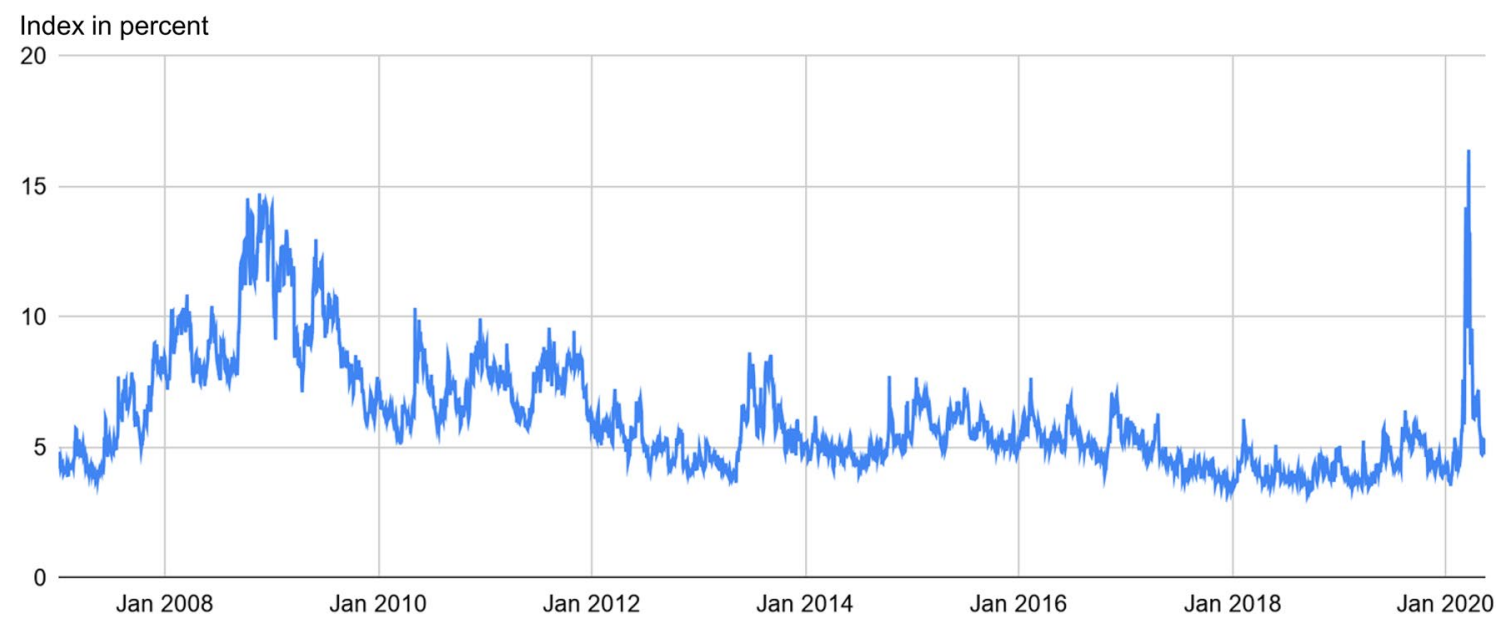

Fig. 3 Implied volatility, 10-year Treasury note futures Source: Federal Reserve Bank of St. Louis, FRED, CBOE

Table 1 2007-2009 and 2020 Federal Reserve facilities and tools

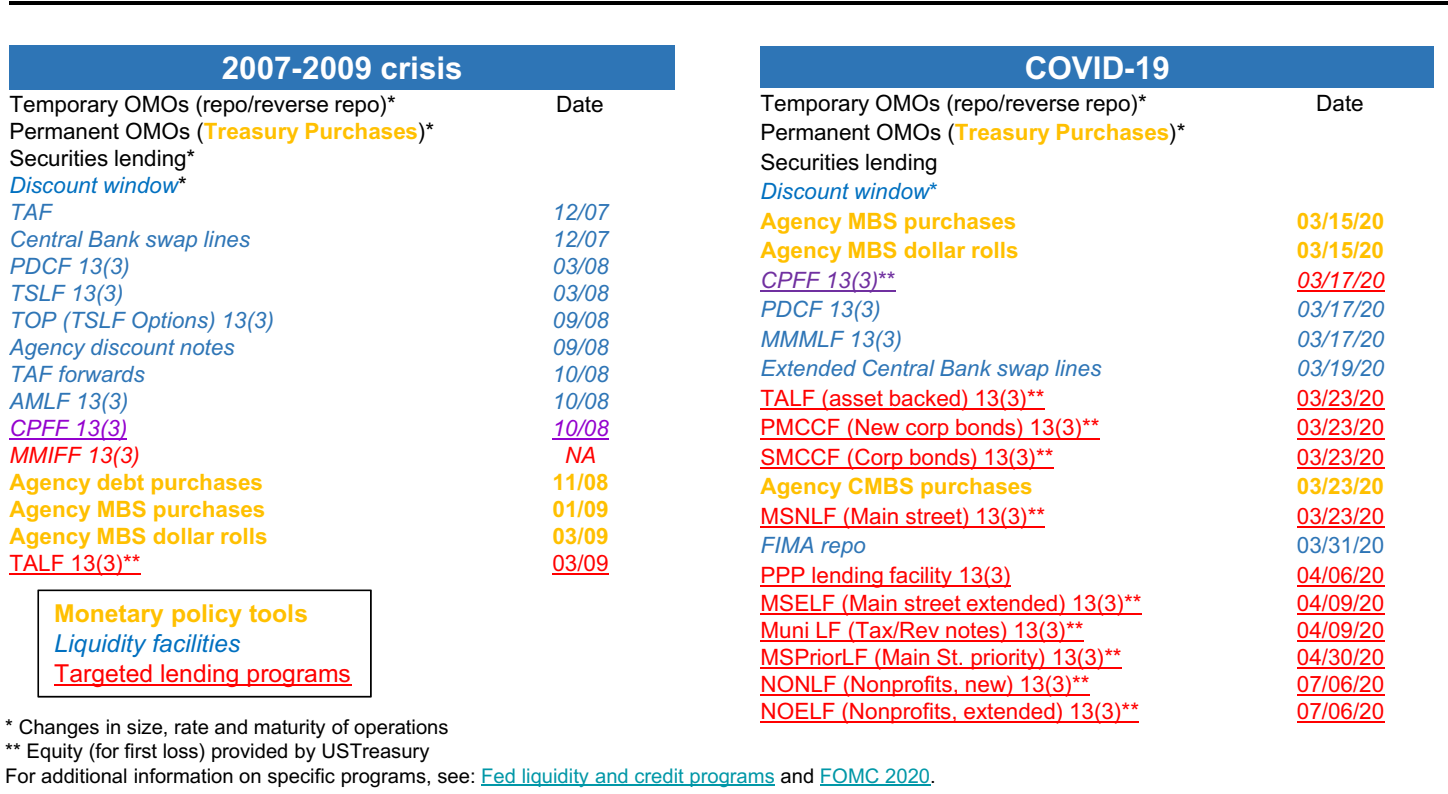

purchases (and other changes to program eligibility) have reduced 10-year euro sovereign bonds by 45 to 100 basis points. The Bank of Japan also expanded asset purchases, but largely of risky assets (corporate bonds, exchange traded funds etc.), and maintained its standing policy of yield curve control, purchasing sufficient quantities of long-term JGBs to keep the 10-year interest rate at approximately zero percent (Bank of Japan 2020).

\subsection{Lender of last resort to the financial system}

The second set of COVID-19 central bank policies were liquidity facilities or lender of last resort to the financial system. Many central banks, most notably the Fed, took out the playbook from
2007 to 2009 financial crisis and recreated nearly all of the lending programs. (See Table 1). The majority of the lenderof-last resort programs were up and running in a couple of weeks. ${ }^{10}$ For example, on March 12 the ECB launched a new round of essentially unlimited long-term refinancing operations (LTROs) for banks at lower borrowing rates $(-50 \mathrm{bps})$, and again in April the ECB announced additional pandemic emergency repo operations through Sept 2020.

\footnotetext{
10 Note that a number of the Fed's liquidity facilities were launched using the Fed's emergency authorities under section 13-3 of the Federal Reserve Act. Such 13-3 facilities, including primary dealer credit facility, commercial paper funding facility and the money market mutual fund liquidity facility, required the approval of the Secretary of the Treasury as per changes made in the Dodd-Frank Act.
} 


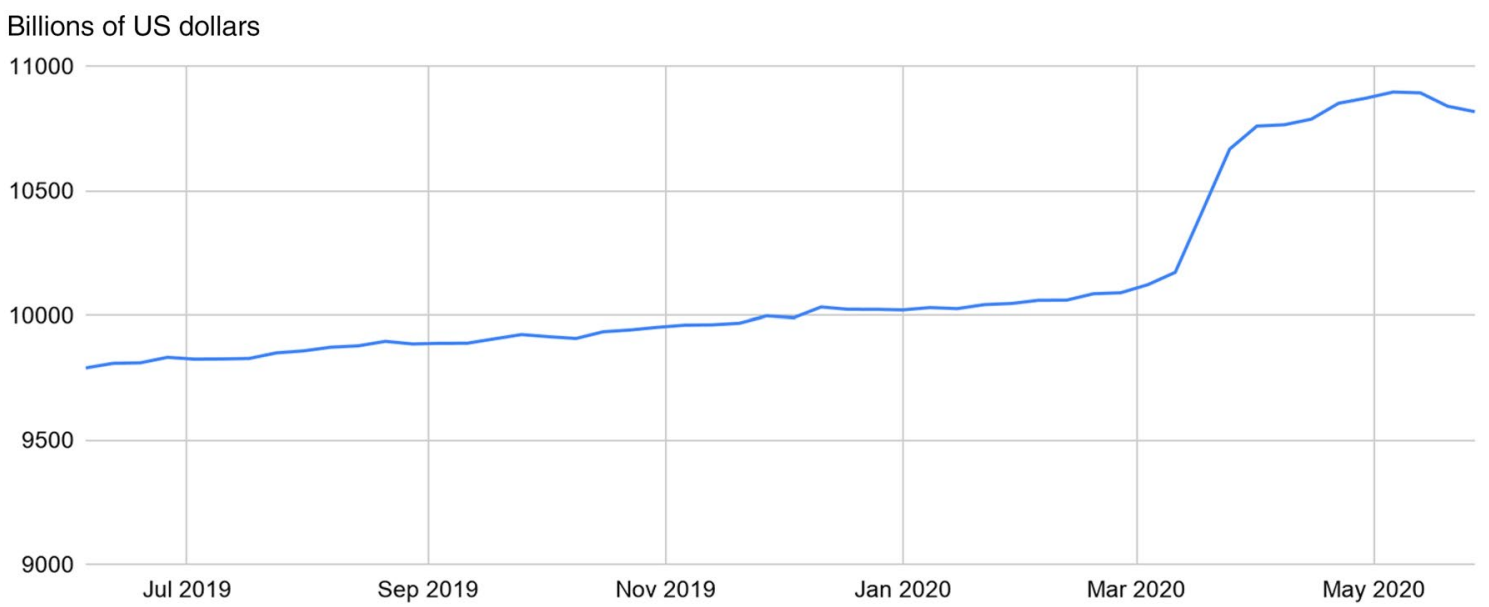

Fig. 4 Loans and leases in bank credit, all commercial banks

Source: Federal Reserve Board of Governors

One change in the liquidity facilities, however, was their pricing. In the 2007-2009 financial crisis, liquidity programs lending to the financial sector in most countries were priced at penalty rates: interest rates that would be considered high relative to private sector borrowing rates in normal times, but attractive during periods of market turmoil and funding shortages. In a financial crisis, penalty rates make sense: they can help manage the moral hazard of financial institutions borrowing excessively from the central bank, and they provide a smooth exit mechanism from liquidity programs as financial conditions improve. But in the COVID crisis, many central banks, including the Fed, reduced the penalty rates on their lender of last resort facilities, reflecting the view that the moral hazard typically associated with central bank liquidity provision was lower, both because the exogenous nature of the COVID shock and because of the relative strength of the financial system. ${ }^{11}$

At the beginning, in March and April 2020 particularly, the large expansion of liquidity to the financial system was necessary. The initial turmoil in both bond and equity markets was severe, reflecting enormous uncertainty about economic and financial conditions. The expectation of large credit losses due to shutdowns caused immediate flight to both liquid and safe assets and concerns about bank safety and soundness. Risky asset prices fell sharply, and volatility spiked. Mutual fund outflows were massive, and some riskier money market mutual funds were run (with proceeds going largely to banks and safe sovereign short-term instruments). Lending for commercial paper issued by both financial and nonfinancial companies dropped sharply and corporate and municipal bond issuance dried up. Nonbank leveraged investors, such as hedge funds and real estate investment trusts,

11 https://www.wsj.com/articles/transcript-fed-vice-chairman-richa rd-clarida-discusses-economy-and-monetary-policy-11590089318. which are particularly dependent on wholesale funding such as repo, faced a loss of funding and large margin calls.

In short, precautionary demand for liquidity across the global economy soared. For example, both financial and nonfinancial customers of U.S. banks drew heavily on their bank lines of credit (Fig. 4).

Initially, liquidity provision by central banks expanded rapidly, particularly in March. Borrowing from the Fed through normal repo operations with securities dealers jumped $70 \%$ in the week of March 18. The new or restarted emergency lender of last resort facilities to finance commercial paper (CPFF), money market risky assets such as commercial paper and short-term municipal notes (MMLF), and to repo risky assets of the primary dealers (PDCF) were drawn on as soon as they were operational. Even the heavily stigmatized and rarely used discount window for banks was tapped.

But unlike the 2007-2009 financial crisis, financial market turmoil was short-lived. In the United States, by early April the combination of massive purchases of U.S. Treasuries, effectively open-ended repo funding for Treasury, Agency and risky debt to major securities firms, emergency funding for $\mathrm{CP}$ and money funds, and the announcements of new targeted lending facilities for the real economy (see below) relieved some of the distress. As a result, the use of the central bank domestic liquidity programs peaked in late March or April and stabilized or declined after that. For most advanced economies, usage has remained small compared to 12 years ago.

Another reason for the modest and shrinking lender of last resort programs was the relative strength of banks and the financial system. Thanks in large part to the massive increases in equity and liquidity buffers, particularly in the global banking industry since the 2007-09 crisis, liquidity needs at the core of the financial system were relatively modest. 
In contrast to domestic liquidity facilities, international lender of last resort facilities-particularly central bank swap lines-were more heavily used and for longer. Because U.S. dollar liquidity shortages are always much worse outside the United States than inside, Fed swaps (lending U.S. dollars for foreign currency collateral) with foreign central banks grew to nearly $\$ 450$ billion by late April. The Federal Reserve also initiated a repo facility for central banks and official institutions who keep U.S. Treasury securities in custody at the New York Fed. The facility allowed a broad array of central banks and official institutions-including those who do not have swap lines with the Fed-to receive U.S. dollar funding in exchange for Treasury collateral. ${ }^{12}$ Other regional swap arrangements for liquidity provision were also activated, and several countries were approved for the IMF's Flexible Credit Line. ${ }^{13}$ But as economic and financial conditions stabilized over the summer, even use of the swap lines declined.

\subsection{Targeted credit programs}

In contrast to monetary policy and liquidity tools, many of the targeted credit programs in various countries are new to the COVID crisis. ${ }^{14}$ As such, the design of these facilities across countries varies significantly, and there is more uncertainty about their effectiveness. That said, the common intent of the programs is to provide government backed "bridge financing" for the real economy: to preserve jobs, to keep open distressed but otherwise solvent firms, to support household finances, and to preserve key public services until the public health crisis has passed. They are targeted lending to a variety of firms, to municipal and state governments, and directly or indirectly to households. The policy purpose is largely analogous to many fiscal policy programs, providing government support-in this case through lending - to weather the pandemic storm.

In countries with active corporate credit markets, central banks introduced or expanded corporate bond and commercial paper purchase programs to support credit to the largest firms. For some central banks, notably the ECB and Bank of Japan, corporate bond purchases are standard operating

\footnotetext{
12 Other large reserve currency central banks also activated liquidity swap lines in their currencies with other central banks. For example, the ECB swap lines with several European countries which were introduced in 2007-2009 were restarted, and the ECB also introduced a euro repo facility available to a broad set of central banks and official institutions.

13 Including Peru and Chile. For information on the IMF's FDL see https://www.imf.org/external/np/exr/facts/pdf/fcl.pdf.

14 Exceptions include the TALF program by the Federal Reserve, corporate bond purchases by many central banks including the ECB, $\mathrm{BOJ}$ and $\mathrm{BOE}$, and funding-for-lending programs at various central banks.
}

procedure in their existing asset purchase programs. Other examples of new (or renewed) corporate bond programs include those by the Bank of Canada, the Swedish Riksbank, the Fed and the Bank of England. ${ }^{15}$

But direct lending to the nonfinancial sector is not typically the responsibility of central banks, and it poses significantly more risk than is typically taken by central banks. For smaller businesses, the lending is so risky, in fact, in a number of jurisdictions, programs are purely fiscal and run directly by government agencies or by national development banks. The Paycheck Protection Program (PPP) in the U.S. is one example. Another is Germany's Quick Loan Programme (KfW-Schnellkredit), managed by KfW, Germany's development bank. Similarly, the UK Coronavirus Business Interruption Lending Scheme for small business is run by the British Business Bank, a UK government-owned development bank. ${ }^{16}$

Because of the higher risk, central bank credit losses in targeted credit programs are often backstopped by the fiscal authorities. In the UK, the Bank of England's business interruption lending programs for large businesses is $80 \%$ guaranteed by the government. In addition, the Bank of England is fully indemnified by the UK government against losses for its corporate bond and commercial paper purchase programs. ${ }^{17}$

The Fed's targeted lending programs are only possible because Congress allocated the U.S. Treasury with $\$ 450$ billion to provide first-loss protection to the Federal Reserve. The Federal Reserve, by statute, cannot take the amount of risk that would be required to do such targeted, unsecured lending on its own, even under its (13-3) emergency lending authorities. Indeed, the structure and particularly the risk tolerances of these programs largely reflect U.S. Treasury risk appetite.

Backed by U.S. Treasury's capital, the Fed introduced and implemented a remarkable variety of targeted credit programs. Four of programs support credit formation in markets-specifically corporate, municipal and securitization markets. The primary (PMCCF) and secondary (SMCCF) corporate bond facilities are aimed at the very largest firms. In the latter, a Fed/Treasury special purpose vehicle (SPV)

\footnotetext{
15 The Bank of Canada also has a provincial (municipal) bond purchase program.

${ }^{16}$ It is notable that the first small business lending program proposed in Germany provided only an $80 \%$ government guarantee, but lack of demand led KfW to create the current Quick Loan Programme,which provides a $100 \%$ guarantee. See https://www.bmwi.de/Redaktion/ EN/Downloads/E/kfw-sonderprog ramm-2020-version-en.pdf? $\mathrm{blob}=$ publicationFile $\& \mathrm{v}=4$.

17 See Bank of England Covid Corporate Financing Facility, at https ://www.bankofengland.co.uk/markets/covid-corporate-financing-facil ity/our-support-for-large-employers-affected-by-the-covid-19-crisis.
} 


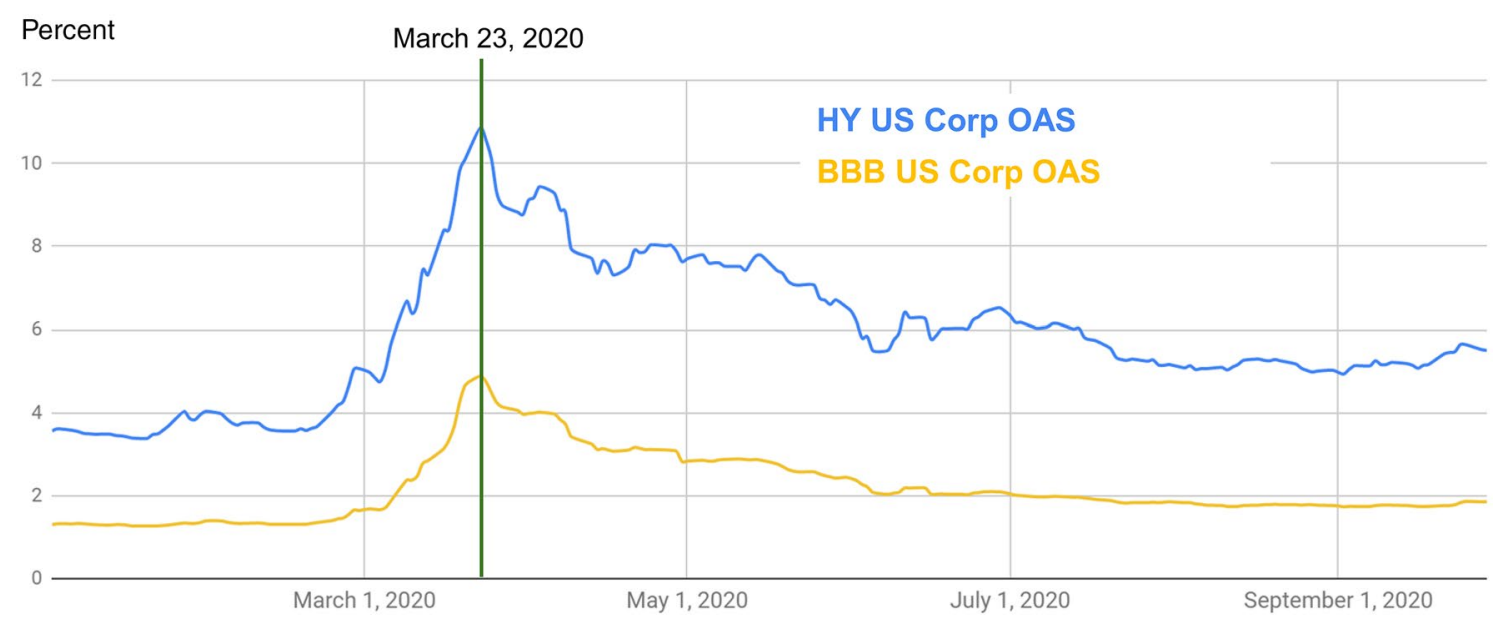

Fig. 5 Corporate bond option adjusted spreads to U.S. Treasury yields Source: ICE Bank of America, Federal Reserve Bank of St. Louis FRED

purchases previously issued corporate bonds and exchange traded funds (ETFs) to maintain enough market liquidity so the creditworthy firms can continue to issue new bonds. The former directly purchases newly issued corporate bonds. ${ }^{18}$ Support for U.S. municipalities and states is provided through a new-issue municipal bond purchase program (again via an SPV) aimed as providing bridge financing for expected future revenue and bond issuance. And last, but certainly not least, is the Term Asset-Backed Securities Loan Facility (TALF) program. It is the only targeted credit program that dates from the 2008 financial crisis and provides collateralized, but nonrecourse, funding to private investors for new securitizations, especially of household credit such as auto loans and credit cards.

But the most complex and riskiest of the Fed's new programs are the Main Street Lending Facilities, which provide credit directly to small and medium sized companies and not-for profits, but with banks processing applications, providing underwriting and taking $10 \%$ risk retention of the loans. ${ }^{19}$

Despite the breadth and potential size of the Fed's targeted credit lending programs, the vast majority of such programs have done a relatively small amount of lending (Oguri 2020). There are several reasons for this. First, the size and speed of the entire package of economic policy responses to COVID-19 allowed the private sector to keep

\footnotetext{
18 While I have classified the CPFF as a (financial) liquidity facility, in fact nonfinancial companies can place commercial paper in the facility, so it can (and has) been used to provide short-term credit to the nonfinancial corporate sector. The quantity of paper that can be placed is limited by size of issuance in 2019. See https://www.feder alreserve.gov/monetarypolicy/files/monetary20200723a1.pdf.

${ }^{19}$ See https://www.federalreserve.gov/monetarypolicy/mainstreet lending.htm
}

lending. The rate cuts, huge asset purchases, massive available liquidity for the global financial system, and just the promise of targeted credit programs had very large and positive announcement effects. Rapid and enormous fiscal policy responses, particularly income support to households and small businesses, was particularly important by supporting economic activity and reducing default risk. By May, credit spreads in bond markets had fallen, although certainly not to pre-COVID levels. Importantly, borrowing via bond markets restarted very quickly, because lenders knew that backstops were either in place or were coming.

These confidence effects prevented a complete collapse in credit and enabled some parts of the real economy-particularly large firms and municipalities - to continue to borrow from the private sector even before the central banks targeted facilities were up and running. In addition, corporate bond spreads, which had risen sharply in mid-March, immediately began to fall when programs were announced on March 23 (Fig. 5). See Liang (2020), Boyarchenko et al (2020), and Gilchrist et al (2020) for empirical evidence on the size of both the announcement and implementation effects of the Fed's corporate purchase programs.

Measuring the impact of bond purchase programs is more easily done than measuring the impact of lending to smaller businesses and households, because the central bank is lending via market-based instruments. Credit prices (interest rate spreads) and credit quantities (bond issuance) can be readily measured. Credit quality of borrowers is more straightforward to determine because of public disclosure requirements in bond markets. For the same reason, central banks' implementation of their bond purchase programs was typically done more quickly than lending programs aimed at smaller borrowers. This was certainly true for the Fed's corporate and municipal bond facilities relative to Main Street programs. 
Many targeted credit facilities were designed as backstops to private credit markets and lending, and as such they are not intended to be heavily used in the present circumstances. In the case of the Fed, purchases of corporate bonds are small because investors continue buy and sell with reasonable liquidity. Few new corporate or municipal bonds have been sold to the Fed, because the private sector investors are willing to finance them at reasonable terms. Indeed, large corporates have increased their liquidity positions and refinanced bank debt by issuing corporate bonds to private investors. See Darmouni and Siani (2020). TALF funding for investors in asset backed securities is expensive compared to financing in the private sector. And the Main Street lending facilities are priced at relatively high interest rates, which are set by the Fed and Treasury, not by private lenders. The Main Street program terms, combined with the complexity of the program, makes the program less attractive. See English and Liang (2020).

Second, some targeted lending programs are small to date because they were slow to start up and complex. Many were designed completely from scratch, and the setup required assessments of new risks and an enormous set of new counterparties whom central banks have little or no experience lending to. ${ }^{20}$ For example the Fed's Main Street facilities provide uncollateralized lending to small and medium sized nonfinancial companies-both things the Fed has not done since the 1930s. The complexity of the many central bank programs reflects complexity of risk sharing arrangementsbetween at least two government authorities (fiscal and the central bank) as well as private lenders. ${ }^{21}$ But complexity can also make the programs less attractive, particularly to smaller borrowers and smaller lenders who have fewer resources to expend on understanding and applying to a new lending scheme.

Third, unlike some fiscal lending programs, such as the U.S. PPP, central bank targeted lending programs are typically not forgivable. There is massive uncertainty about both the length and the shape of the pandemic and the restructuring of the real economy that will follow in the medium and longer term. In light of that uncertainty, it is not surprising that firms and households are exceptionally cautious about taking on more debt, and that financial companies are cautious about additional lending, even if exposures are low.

As an alternative to direct credit lending programs, a number of central banks in advanced and emerging economies have begun (or reinstated) funding-for-lending

\footnotetext{
20 Targeted credit programs in many countries-whether done by the fiscal authorities or by the central bank-have been repeatedly revised based on lessons learned. The U.S. PPP and Main Street facilities are good examples.

${ }^{21}$ Even the TALF program, which was used to help restart nonmortgage asset backed securities markets in 2009 and 2010, was complicated enough that it took three months to set up in 2020 .
}

programs to support credit to the nonfinancial sector. ${ }^{22}$ The ECB is an example. While the ECB has increased purchases of corporate bonds as a part of its asset purchase programs, support for small and medium sized business and household credit formation is done by subsidizing euro-area bank funding costs through Targeted Long-Term Refinancing Operations (TLTROs). Banks who demonstrate that a sufficient share of additional funding from the ECB was used to support real economy credit formation may borrow funds at $-1.00 \%, 50$ basis points below the interest rate paid on reserves. ${ }^{23}$ Funding-for lending programs can be limited by the available capital in the banking industry and by the need for ex post verification, the requirement that private lenders make loans to a particular sector. In addition, they are typically not priced to be backstops to private markets. However, funding-for-lending schemes typically do not require fiscal authorities to provide backstops, since the central bank lends to banks and other lenders against collateral. Private lenders have some control over the interest rates they charge to borrowers. Overall, funding-for-lending programs in 2020 have also been more widely used, which is perhaps not surprising since they typically have low (subsidized) interest rates, use existing counterparty relationships and on the whole may be less complicated that some direct lending programs.

\subsection{Challenges and risks for central bank policy}

Despite their reputations as staid, risk averse institutions, central banks are typically on the front line of risk-taking during crises, and COVID is no exception. However, the unique nature of this crisis and the quasi-fiscal nature of many programs poses risks for central banks.

The biggest near-term risk is that continued waves of the virus cause further widespread shutdowns and further legs down in economic activity. If defaults and bankruptcies mount, the earlier positive confidence effects in financial markets can evaporate, borrowing costs could rise sharply, and private lenders will no longer be willing or able to sustain credit. In that case, central bank and government credit facilities will be needed not just as backstops, and perhaps in very large size.

Second, there is significant risk that targeted credit policies, particularly those for small businesses and households, don't work as well as central banks and governments expect when they are needed. They may be too expensive, restrictive or complicated for borrowers and lenders to use. Starting new programs or making adjustment to existing programs

\footnotetext{
${ }^{22}$ See Nygaard (2020). For example, the Bank of England, Reserve Bank of Australia, and the central banks of Taiwan and Saudi Arabia.

${ }^{23}$ https://www.ecb.europa.eu/press/pr/date/2020/html/ecb.pr200 430 fa46f38486.en.html.
} 
will cause further delays and risk of further economic damage. See Crouzet and Gourio (2020).

Third, governments might decide they cannot or do not want to assume too much fiscal risk directly supporting firms and households, particularly firms and industries which may no longer be viable after the pandemic ends. For advanced economies who have more fiscal space, this is a choice. For example, governments may prefer to spend their fiscal firepower on income support rather than providing first loss protection to central bank lending programs-particularly when there is enormous uncertainty about companies' ability to repay in the future even under generous terms. Or they may simply determine that additional fiscal expansion is imprudent. In emerging economies, the choices are often more stark. More limited ability to borrow can put a severe limit on size of fiscal and monetary programs provided in EMs. And history suggests that because of stigma, countries may be slow to seek assistance from multilateral institutions. In this case, monetary policy and traditional liquidity provision to banks and the financial sector may be the main domestic mechanisms for support to the economy. But having central banks again be "the only game in town" is particularly dangerous in the COVID crisis, since at its core it is not a financial crisis, but a real economy one.

Fourth, the COVID crisis has significantly increased the debt levels across the economy, sometimes directly as the result of central bank and government policies. While this increase in leverage has had a positive countercyclical impact on the economy to date, it may also limit the ability of the economy and governments to recover rapidly afterward. Moreover, central banks have taken much larger amounts of public and private debt onto their balance sheets, monetizing it. For the large advanced economies, the prospect of zero interest rates for the foreseeable future appear to make these risks manageable. But the trajectory of the COVID crisis is uniquely uncertain in terms of its length, depth and the degree of long-run structural economic change it will cause. See Baker et al. (2020). The nonfinancial business sector in many countries was already highly leveraged going into the crisis. Could debt overhang impair the ability of the private sector to restructure and grow afterward, similar to the U.S. household debt overhang after the 200709 financial crisis? If high debt levels now mean that governments will need to tighten fiscal policy significantly in the recovery, will that impair their ability to assist in the necessary restructuring of industry and labor markets? And, of course, how much debt—public and private-should central banks finance now?

The size and scope of central bank policy actions in the COVID crisis may pose risks to their long-standing operational independence in the monetary policy realm. First, the sheer credit risk taken by central banks has grown significantly. Central banks programs will likely show significant credit losses-particularly from their targeted lending programs. ${ }^{24}$ Even when a central bank has a fiscal backstop, the political risk is high both in terms of blame for losses to taxpayers and blame for refusing to lend (i.e. save) certain counterparties. To a greater degree than in the past, central banks are picking winners and losers, through the corporate and municipal bonds they chose to buy and through the structure of targeted lending programs. From a political standpoint, central bank programs for financing municipal debt seem particularly fraught. By creating quasi-fiscal lending programs, central bank coordination with fiscal authorities may be sound policy in the current extreme circumstances, but central banks risk facing much more significant political scrutiny and oversight, which may not be limited just to those programs.

Finally, it is important to note the impact of COVID19 to date on central bank balance sheets, and what that may tell us about future central bank actions. If the economic recovery is slow, large asset purchases and very low interest rates will go on a long time and central bank balance sheets will be much larger. ${ }^{25}$ For the large advanced economy central banks, balance sheets will be enormous and filled with long-term and riskier assets which may be held for decades rather than years. Figure 6 shows the balance sheets of the Fed, the ECB and the Bank of Japan as a percent of GDP. Nearly all of the growth in the balance sheets in 2020 reflects purchases of long-term assets. In the case of the Fed, the balance sheet exploded from $\$ 4.3$ trillion to $\$ 7$ trillion in the space of 2 months (see Fig. 7). Since then the Fed's balance sheet has stabilized, as ongoing purchases of Treasury and agency mortgage-backed securities (and small purchases of corporate and municipal bonds) have been offset by declines in lender-of-last-resort funding. But going forward, the Fed's balance sheet, like those of the ECB and BOJ, will continue to grow as asset purchases continue., If credit conditions significantly deteriorate, both liquidity programs and targeted credit could also increase sharply. While fiscal dominance is a remote risk for the largest economies and central banks, in the current daunting circumstances it could become a challenge for some emerging and developing economies.

\footnotetext{
${ }^{24}$ For the Fed, the contrast with $2007-2009$ is interesting. The Fed has had no credit losses from any lending programs in 2007-2009. If their current targeted lending facilities are used, it is highly likely that they will take losses.

25 And within the Federal Reserve's new monetary policy framework, QE and zero interest rates may last a particularly long time, until inflation is above the $2 \%$ long-term target for some time. (See FOMC 2020c).
} 


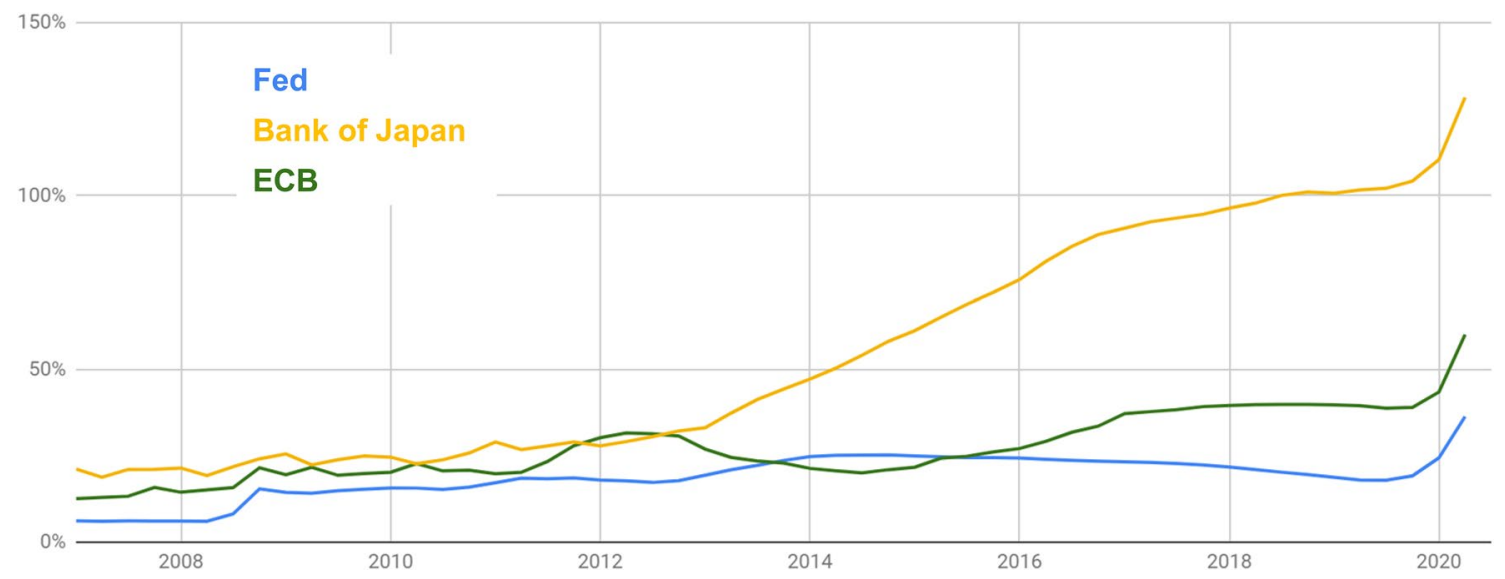

Fig. 6 Central banks' balance sheets as a percent of nominal GDP Source: Federal Reserve Bank of St. Louis, FRED

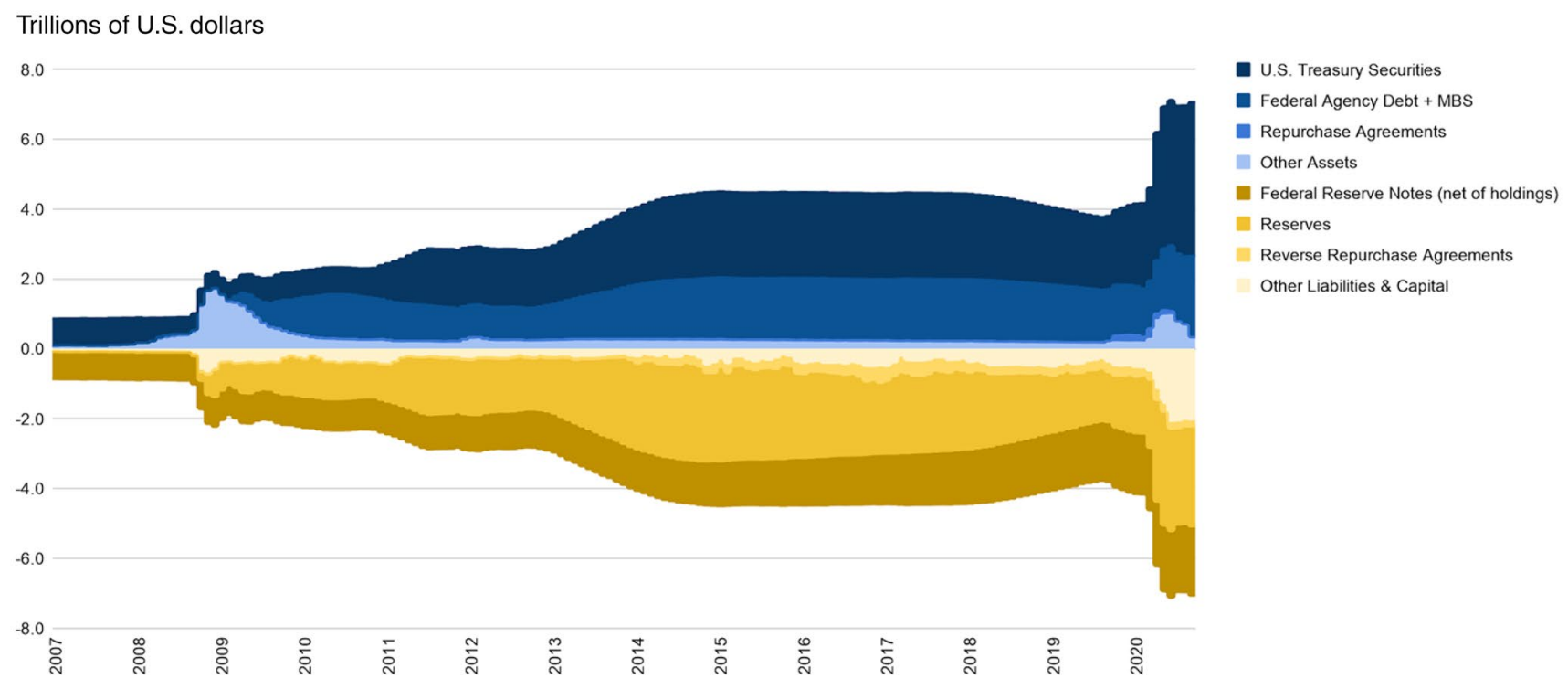

Fig. 7 The Federal Reserve's balance sheet

Source: Federal Reserve Board of Governors

\section{Conclusion}

To a surprising degree financial markets and lenders were able to look beyond the economic cliff during the first few months of the COVID crisis, due in part to very large and swift policy actions by central banks. Much easier monetary policy, massive liquidity provision, and direct credit support to the real economy all played a role in stabilizing financial conditions and credit. Initial central bank policy responsesproviding liquidity and exceptionally large asset purchasesstabilized financial conditions quickly in March and April, while announcements of upcoming targeted credit programs for the real economy by both fiscal and monetary authorities gave investors and lenders the confidence to lend at reasonable, rather than astronomical interest rates.
But central bank policy can only indirectly address the core economic policy challenges of the crisis, which is ongoing, and whose trajectory remains highly uncertain. While central bank policy can continue to play its role, the first six months of the crisis has made it clear that it cannot (or rather should not) do so alone. And, so, the risks to the economy and financial system remain very large. In the near-term there is uncertainty about the willingness and ability of fiscal authorities to support incomes and economic activity, about the limits on central bank lending and risk taking, and about the efficacy of overreliance on central bank policies given the impact on leverage and debt levels. The longer term challenges are equally large: restarting economic growth, deleveraging the economy and managing what are likely to be large structural changes coming out the pandemic. 


\section{References}

Baker, Scott R., Nicholas Bloom, Steven J. Davis, and Stephen. J. Terry. 2020. Covid-Induced Economic Uncertainty. National Bureau of Economic Research Working Paper 26983. https:// www.nber.org/papers/w26983.

Bank of Japan. 2020. Enhancement of Monetary Easing. https:// www.boj.or.jp/en/announcements/release_2020/k200427a.pdf.

Borio, Claudio. 2020. The Covid-19 Economic Crisis: Dangerously Unique. Business Economics 55(4).

Boyarchenko, Nina, Anna Kovner and Or Shachar. 2020. It's What You Say and What You Buy: A Holistic Evaluation of the Corporate Credit Facilities, Staff Report \#935, Federal Reserve Bank of New York. https://www.newyorkfed.org/research/staff _reports/sr935.

Crouzet, Nicholas and François Gourio. 2020. Financial Positions of U.S. Public Corporations: Part 5, The Main Street Lending Program: Potential Benefits and Costs Chicago Fed Insights June 18 https://www.chicagofed.org/publications/blogs/chica go-fed-insights/2020/financial-positions-part5.

Darmouni, Olivier and Kerry Siani. 2020. Crowding Out Bank Loans: Liquidity-Driven Bond Issuance. https://papers.ssrn. com/sol3/papers.cfm?abstract_id=3693282.

Duffie, Darrell. 2020. Still the World's Safe Haven? Redesigning the U.S. Treasury Market After the COVID19 Crisis. Hutchins Center Working Paper \#56, Brookings Institution. https:// www.brookings.edu/wp-content/uploads/2020/05/WP62_Duffi e_v2.pdf.

ECB. 2020. Pandemic Emergency Purchase Programme (PEPP). https://www.ecb.europa.eu/mopo/implement/pepp/html/index .en.html. . Accessed Feb 10, 2020.

English, William B. and J. Nellie Liang. 2020. Designing the Main Street Lending Program: Challenges and Options. Hutchins Center Working Paper \#64, Brookings Institution. https://www. brookings.edu/wp-content/uploads/2020/06/WP64_Liang-Engli sh_FINAL.pdf.

Federal Reserve Board. 2020. Commercial Paper Funding Facility, Terms and Conditions. https://www.federalreserve.gov/monet arypolicy/files/monetary20200723a1.pdf.

FOMC. 2020a. March 15, 2020 Federal Open Market Committee Statement. https://www.federalreserve.gov/monetarypolicy/files /monetary20200315a1.pdf.

FOMC. 2020b. March 23, 2020 Federal Open Market Committee Statement. https://www.federalreserve.gov/monetarypolicy/files /monetary20200323a1.pdf.

FOMC. 2020c. Statement of Longer-run Goals and Monetary Policy Strategy. https://www.federalreserve.gov/monetarypolicy/revie w-of-monetary-policy-strategy-tools-and-communications-state ment-on-longer-run-goals-monetary-policy-strategy.htm August 27, 2020 .

Fleming, Michael, Asani Sarkar, and Peter Van Tassel. 2020. The Covid-19 Pandemic and the Fed's Response. Liberty Street Economics April 15. https://libertystreeteconomics.newyo rkfed.org/2020/04/the-covid-19-pandemic-and-the-feds-respo nse.html.

Fleming, Michael. 2020. Treasury Market Liquidity and the Federal Reserve during the COVID-19 Pandemic. Liberty Street Economics May 29. https://libertystreeteconomics.newyorkfed .org/2020/05/treasury-market-liquidity-and-the-federal-reserveduring-the-covid-19-pandemic.html.

Gilchrist, Simon, Bin Wei, Vivian Z. Yue, and Egon Zakrajšek. 2020. The Fed Takes on Corporate Credit Risk: Analysis of the Efficacy of the SMMCF. National Bureau of Economic Research Working Paper 27809. https://www.nber.org/papers/w27809.

Guerrieri, Veronica, Guido Lorenzoni, Ludwig Straub, and Iván Werning. 2020. Macroeconomic Implications of COVID-19: Can Negative Supply Shocks Cause Demand Shortages? National Bureau of Economic Research Working Paper \#26918. https:// www.nber.org/papers/w26918.

IMF. 2020. Policy Responses to COVID-19. IMF Policy Tracker September 11. https://www.imf.org/en/Topics/imf-and-covid19/ Policy-Responses-to-COVID-19\#B.

Lewis, Daniel, Karel Mertens and Jim Stock. 2020. Monitoring Real Activity in Real Time: The Weekly Economic Index. Federal Reserve Bank of New York Liberty Street Economics March 30. https://libertystreeteconomics.newyorkfed.org/2020/03/monit oring-real-activity-in-real-time-the-weekly-economic-index .html.

Liang, J.Nellie. 2020. Corporate Bond Market Dysfunction During COVID-19 and Lessons from the Fed's Response, Hutchins Center Working Paper \#69, Brookings Institution. https://www. brookings.edu/wp-content/uploads/2020/10/WP69-Liang_1.pdf.

Ma, Yiming, Kairong Xiao and, Yao Zeng. 2020. Mutual Fund Liquidity Transformation and Reverse Flight to Liquidity. https $: / /$ ssrn.com/abstract $=3640861$.

Nygaard, Kaleb. 2020. Central Banks Launch Funding for Lending Programs. Program on Financial Stability, Yale School of Management. https://som.yale.edu/blog/central-banks-launch-fundi ng-for-lending-programs.

Oguri, Junko. 2020. Use of Federal Reserve Programs Program on Financial Stability, Yale School of Management. https://som. yale.edu/blog/use-of-federal-reserve-programs-09232020.

Publisher's Note Springer Nature remains neutral with regard to jurisdictional claims in published maps and institutional affiliations.

Patricia C. Mosser is Director of the MPA Program in Economic Policy Management at Columbia University's School of International and Public Affairs and leads the school's Initiative on Central Banking and Financial Policy. Previously, she was head of Research and Analysis at the Office of Financial Research, U.S. Treasury. Mosser spent over 20 years at the Federal Reserve Bank of New York where she was senior manager at the New York Fed's open market desk overseeing financial market analysis, monetary policy implementation, crisis-related facilities, foreign exchange and investment operations, and analysis of financial stability. In 2009, she was SOMA manager for the FOMC. She previously served as an economist and manager in the New York Fed Research Department and as an assistant professor in the Economics Department at Columbia. Mosser has written on financial stability and monetary policy topics including financial reform, crisis policy tools, cyber risks to financial stability, and the monetary transmission mechanism. She received a BA from Wellesley College, an MSc with distinction from the LSE, and a PhD in economics from MIT. 